\title{
Alüminyum, Magnezyum ve Çelik Malzemelerle Tasarlanmış Tek Hücreli ve Çok Hücreli Çarpışma Kutularının Çarpışma Performanslarının İncelenmesi
}

\author{
Emre İsa ALBAK*1 \\ ${ }^{1}$ Bursa Uludă̆ Üniversitesi, Gemlik Asım Kocabıyık MYO, Hibrid ve Elektrikli Taşıtlar \\ Teknolojisi Programi, Bursa
}

Geliş tarihi: 24.04 .2021

Kabul tarihi: 30.06 .2021

$\ddot{\mathbf{O z}}$

Çarpışma kutuları, olası bir kaza esnasında sürücü ve araç içi yolcularda oluşabilecek yaralanmaları en aza indirmek için kullanılan pasif güvenlik sistemi elemanlarındandır. Araştırmacılar çarpışma kutularının çarpışma performansını iyileştirmek için farklı yapılar ve malzemeler kullanmaktadır. Bu çalışmada alüminyum alaşım AA6061-O, magnezyum alaşım AZ31B ve DP600 çeliğinden tasarlanan kare, altıgen ve dairesel dış duvara sahip tek hücreli ve çok hücreli olmak üzere dokuz farklı çarpışma kutusu sonlu elemanlar analizi ile incelenmiştir. Çalışmada kullanılan sonlu elemanlar modelleri literatürden elde edilen deneysel veriler ile doğrulanmıştır. Farklı malzemelerden tasarlanmış çarpışma kutuları en büyük çarpışma kuvveti, çarpışma kuvveti verimi ve özgül enerji sönümleme kapasiteleri açısından incelenmiştir. İnceleme sonucunda aynı kesite sahip çarpışma kutuları içinde yırtılmalara maruz kalmasına rağmen AZ31B malzemeli modellerin daha yüksek özgül enerji sönümleme kapasitesine sahip olduğu görülmüştür. Ayrıca çok hücreli yapılar tek hücreli yapılara daha iyi çarpışma performansı sergilemiştir.

Anahtar Kelimeler: Alüminyum alaşım, Magnezyum alaşım, DP600, Çarpışma kutusu, Otomotiv malzemeleri

\section{Investigation for Crashworthiness Performance of Single-cell and Multi-cell Crash Boxes Designed with Aluminum, Magnesium and Steel Materials}

\begin{abstract}
Crash boxes are one of the passive safety system elements used to minimize injuries to drivers and passengers during a possible accident. Researchers use different structures and materials to enhance the crashworthiness performance of crash boxes. In this study, designed from aluminum alloy AA6061-O, magnesium alloy AZ31B and DP600 steel, nine different collision boxes, single-cell and multi-cell with square, hexagonal and circular outer walls, are examined by finite element analysis. The finite element
\end{abstract}

\footnotetext{
*Sorumlu yazar (Corresponding author): Emre İsa ALBAK, emrealbak@uludag.edu.tr
} 
model used in the study has been validated with the experimental data obtained from the literature. Crash boxes designed from different materials have been examined in terms of the maximum crash force, crush force efficiency and specific energy absorption capacity. As a result of the examination, although failures are observed in crash boxes with the same cross-section, it is observed that models with AZ31B material had higher specific energy absorption capacity. In addition, multi-cell structures have shown better crash performance than single-cell structures.

Keywords: Aluminum alloy, Magnesium alloy, DP600, Crash box, Automotive materials

\section{GíRiș}

Çarpışma kutuları, olası bir kaza esnasında sürücü ve araç içinde bulunan yolcularda oluşabilecek yaralanmaları en aza indirmek için kullanılan pasif güvenlik sistemi elemanlarındandır. Çarpışma kutuları, kaza sırasında oluşan enerjiyi plastik deformasyona uğrayarak sönümlemektedir. Gelişen teknoloji ile birlikte otomobillerden hem performans hem de güvenlik beklentileri artmaktadır. Ayrıca çevre kirliliğinin artması nedeniyle artan egzoz gazı emisyonu k1sitlamaları daha hafif otomobillere olan gereksinimi arttırmaktadır. $\mathrm{Bu}$ nedenle araştırmacılar, çarpışma kutularının daha hafif ve daha performanslı tasarımı için farklı geometrik yapı ve malzemeler ile birçok araştırma sunmuşlardır.

Çarpışma kutuları ilk başlarda kare [1,2], altıgen $[3,4]$ ve daire $[5,6]$ gibi temel geometrik kesitler üzerinden incelenmiştir. Tarlochan ve arkadaşları [7], kare, dikdörtgen, altıgen, sekizgen, daire ve elips geometrik şekillere sahip çelik malzemeyle tasarlanmış çarpışma kutularını eksenel ve $30^{\circ}$ açılı eğik çarpma analizleri ile incelemiştir. Çalışmaları sonucunda, altıgen kesitli çarpışma kutusunun, çarpışma performans göstergelerinin yanı sıra maliyet ve üretim fizibilitesi de hesaba katıldığında enerji sönümleyici uygulaması için daha iyi bir konsept olduğu bulunmuştur. Yamashita ve arkadaşları [8], dört, beş, altı, on iki ve doksan altı köşegene sahip alüminyum malzeme ile tasarlanmış çarpışma kutularını incelemiştir. Ayrıca kare ve dairesel çarpışma kutularını da deneysel olarak incelemişlerdir. Çalışma sonucunda, düzenli bir ezilme meydana gelmesi için altı köşegenden az köşegene sahip kesitlerden kaçınılması gerektiği ve çarpışma dayanımının dairesel yapılarda kare kesite göre daha yüksek olduğunu ortaya koymuşlardır.

Son zamanlarda çarpışma kutularının performansını iyileştirmek için çok hücreli yapılar üzerine çalışmalar yapılmıştır. Zhang ve Zhang [9], eksenel basma şartlarında tek hücreli ve çok hücreli yapıların çarpışma karakteristiklerini incelemiştir. Sonuçlar, çok hücreli ince duvarlı tüplerin enerji emme performansının, tek hücreli ince duvarlı tüplerden önemli ölçüde yüksek olduğunu göstermiştir. Huang ve $\mathrm{Xu}$ [10], bir karides türünün fiziksel özelliklerinden esinlenerek oluşturdukları on farklı dairesel dış duvarlı çok hücreli yapıyı eksenel ve açılı yükleme şartlarında incelemişlerdir. Qiu ve arkadaşları [11], altıgen kesitli farklı sayıda hücreye sahip yapıların çarpışma performanslarını eksenel ve açılı yükleme şartlarında incelemişlerdir. Çalışmaları, aynı hücre sayısı için, köşe sayısının enerji emilimini arttırmada önemli bir rol oynadığı ortaya koymuştur.

Çarpışma kutularının performansını iyileştirmek için farklı malzeme kullanımı da araştırmacılar tarafından tercih edilen diğer bir yöntemdir. Çarpışma kutularında kullanılan malzemelerden bazıları alüminyum, magnezyum ve çeliktir. Çift fazlı (DP) olarak isimlendirilen gelişmiş yüksek mukavemetli saclar yüksek mukavemetleri nedeniyle araç ağırlığını azaltmaya katkı sağladığı için otomotiv endüstrisinde tercih edilmektedir [12]. Alüminyum ve magnezyum alaşımlar, düşük yoğunlukları nedeniyle hafif araç tasarımında otomotiv endüstrisinde popüler hale gelmektedir [13]. Demirci ve Yildiz [13], kare, dikdörtgen, dairesel ve çokgen kesitli çarpışma kutuları için çelik, DP ve TRIP çelikleri ile alüminyum ve magnezyum alaşım malzemeleri kullanarak sonlu elemanlar analizleri 
gerçekleştirmiştir. Malzeme karşılaştırma sonuçlarına göre, gelişmiş yüksek mukavemetli çelik ve düşük yoğunluklu alaşımların geleneksel çelikten daha iyi performans göstermiştir. Çelikten yapılan çarpışma kutuların enerji sönümleme kabiliyetleri alüminyum ve magnezyum yapılara göre daha iyi olmakla birlikte, düşük yoğunluklu malzemelerden yapılan enerji sönümleyiciler, geleneksel ve gelişmiş yüksek mukavemetli çelikler kullanılarak yapılanlara göre birim kütle başına daha fazla enerji sönümlemiştir. Kurtuluş ve Tekin [14], farklı kesitlere sahip çarpışma kutularını alüminyum ve magnezyum alaşım malzemeler kullanarak karşılaştırmıştır. Çalışma sonucunda magnezyum tasarımların alüminyum tasarıma göre \%10 oranında daha iyi çarpışma kuvvetine sahip olduğu ve \%60 daha hafif bir tasarıma sahip olduğunu ortaya koymuşlardır.

$\mathrm{Bu}$ çalışmada çift fazlı yüksek mukavemetli DP600 çeliği, AA6061-O alüminyum alaşımı ve AZ31B magnezyum alaşımları kullanılarak dokuz farklı çarpışma kutusunun çarpışma performansları incelenmiştir. Çarpışma kutularının tasarımı, literatürde en çok incelenen kesitlerden olan kare, altıgen ve daire kesitler ile bu kesitlerin çok hücreli yapıları göz önünde bulundurularak üretilmiştir. Çarpışma kutularının performansları, $0,5 \mathrm{~mm} / \mathrm{s}$ sabit hizda basma analizleri yapılarak incelenmiştir.

\section{YÖNTEM}

\section{1. Çarpışma Performansı Parametreleri}

Çarpışma kutularının performansını incelemek için araştırmacılar tarafından performans parametreleri ortaya koyulmuştur. Literatürde en çok incelenen çarpışma performansı parametreleri en büyük çarpışma kuvveti (EÇK), çarpışma kuvveti verimi (ÇKV) ve özgül enerji sönümleme kapasitesidir (ÖES) [15].

En büyük çarpışma kuvveti (EÇK), çarpışma süresince ortaya çıkan en büyük çarpışma kuvvetidir.
Özgül enerji sönümleme kapasitesi (ÖES), çarpışma kutusunun ağırlığının, çarpışma kutusunun sönümlediği toplam enerjiye bölünmesiyle bulunur. Toplam sönümlenen enerji ise kuvvet yer değiştirme eğrisi altında kalan alan hesaplanarak bulunabilir. Burada özgül sönümleme enerji şu şekilde hesaplanabilir (Eşitlik 1):

ÖES $=\frac{\int_{0}^{d} F(x) d x}{m}$

burada $F(x)$ çarpışma kuvvetini, $m$ çarpışma kutusunun ağırlığını ve $d$ ise eksenel yöndeki yer değiştirmeyi temsil etmektedir.

Çarpışma kuvveti verimi (ÇKV) ise ortalama çarpışma kuvvetinin en büyük çarpışma kuvvetine bölünmesiyle hesaplanır. Ortalama çarpışma kuvveti ise toplam sönümlenen enerjinin eksenel yöndeki yer değiştirmeye bölünmesiyle bulunur. Buradan ÇKV aşağıdaki şekilde verilir (Eşitlik 2):

$C ̧ K V=\frac{\frac{\int_{0}^{d} F(x) d x}{D}}{E C ̧ K}$

burada $D$ eksenel yöndeki toplam yer değiştirmeyi temsil etmektedir.

\section{2. Çarpışma Kutusu Tasarımları}

Bu çalışmada literatürde en çok incelenen kesitlerden olan kare, altıgen ve dairesel kesitler ele alınarak tasarımlar oluşturulmuştur. Sadece daire, kare ve altıgen kesitlerden oluşan çarpışma kutuları sırasıyla D1, K1 ve A1 isimleriyle adlandırılmıştır. Daire ve kare yapıların eşit dört parçaya bölünmüş halleri sırasıyla D2 ve K2 olarak adlandırılmıştır. Altıgen yapının ortasından geçen duvarı üç eşit parçaya bölecek şekilde oluşturulan altı hücreli altıgen yap1 A2 ismi ile anılacaktır. Daire, kare ve altıgen yapıların yarısı olacak şekilde içerilerine aynı yapıların yerleştirilmesi ve ek duvarlar eklenmesiyle elde edilen yapilar ise D3, K3 ve A3 isimleriyle adlandırılmıştır. Çarpışma kutularında kullanılan malzemeler olan DP600 çeliği, AA6061-O alüminyum alaşımı ve AZ31B magnezyum alaşımı için sırasıyla çarpışma kutusu isimlerine "DP", "Al” 
ve "Mg" önekleri eklenmiştir. Çalışmada kullanılan çarpışma kutularının kesitleri ve ölçüleri Şekil 1'de verilmiştir. Bütün çarpışma kutularının duvar kalınlıkları 1,00 mm ve uzunlukları ise $120 \mathrm{~mm}$ 'dir.

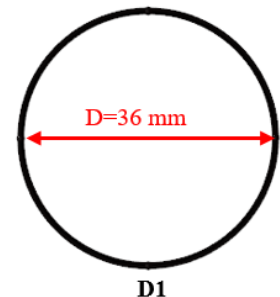

D1
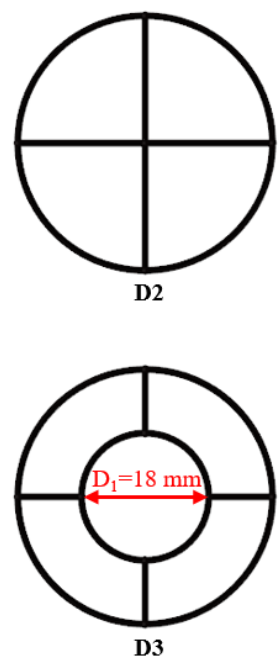

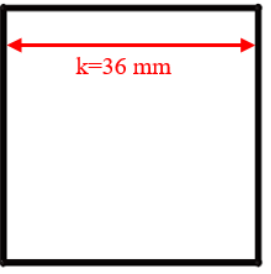

K1
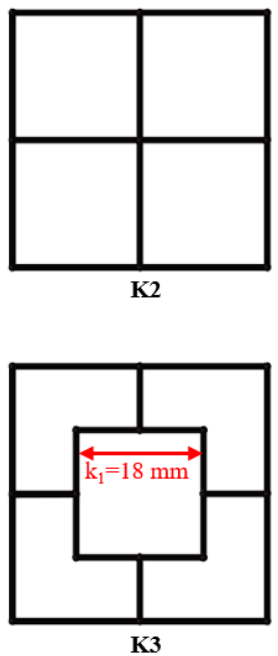
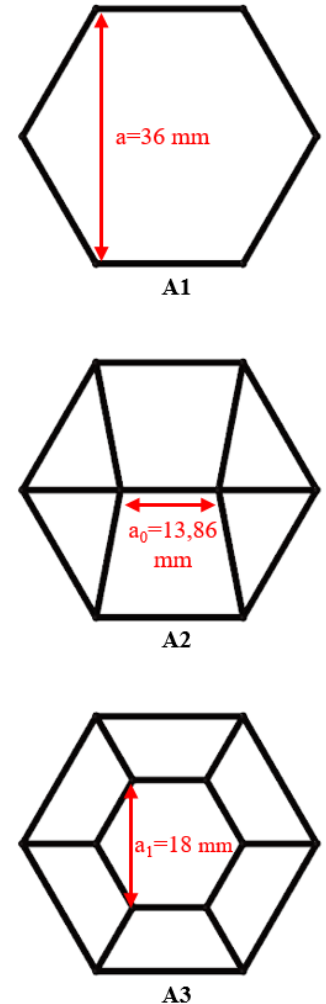

Şekil 1. Çarpışma kutusu kesitleri

\subsection{Sonlu Elemanlar Modeli}

Çarpışma kutularının çarpışma performanslarını incelemek için sonlu eleman yöntemi kullanılmıştır. Sonlu elemanlar modelleri Radioss çözücüsü kullanılarak çözdürülmüştür [16]. Çalışmada kullanılan sonlu elemanlar modeli Şekil 2'de verilmiştir. Sonlu elemanlar modeli $0,5 \mathrm{~mm} / \mathrm{s}$ 'lik düşey yönde basma yapan hareketli duvar, çarpışma kutusunun altında sabitlenmiş sabit taban ve çarpışma kutusundan oluşmaktadır. Çarpışma kutuları 2 boyutlu elemanlarla modellenmiştir. Çarpışma kutularında ortalama eleman boyutu $1,2 \mathrm{~mm}$ olarak belirlenmiştir. Çarpışma kutusunun kendi içinde temasını tanımlamak için Type7 kontak tanımlaması uygulanmıştır. Sonlu elemanlar analizleri, hareketli duvar $120 \mathrm{~mm}$ düşey yönde hareket edecek şekilde yapılmıştır. Çelik ve alüminyum çarpışma kutuları için Mat36, magnezyum için ise Mat66 malzeme kartları tanımlanmıştır. Mat36 malzeme kartı farklı gerinim oranlarındaki gerinme-gerilme eğrileri girilebildiği için seçilmiştir. Çalışmada düşük hızlarda basma analizleri yapıldığı için çelik ve alüminyum malzemelerine tek gerinim değerinde eğriler girilmiştir. Magnezyum malzemelerin çekme ve basma karakteristikleri farklı olduğunda bu malzeme için hem basma hem de çekme sonucu elde edilen gerinme-gerilme eğrilerinin tanımlanabileceği Mat66 malzeme kartı kullanılmıştır. Ayrıca magnezyum malzemeler basma esnasında yırtılma ve kırılmalara maruz kaldığı için Jonhson-Cook hasar kriteri tanımlanmıştır. 


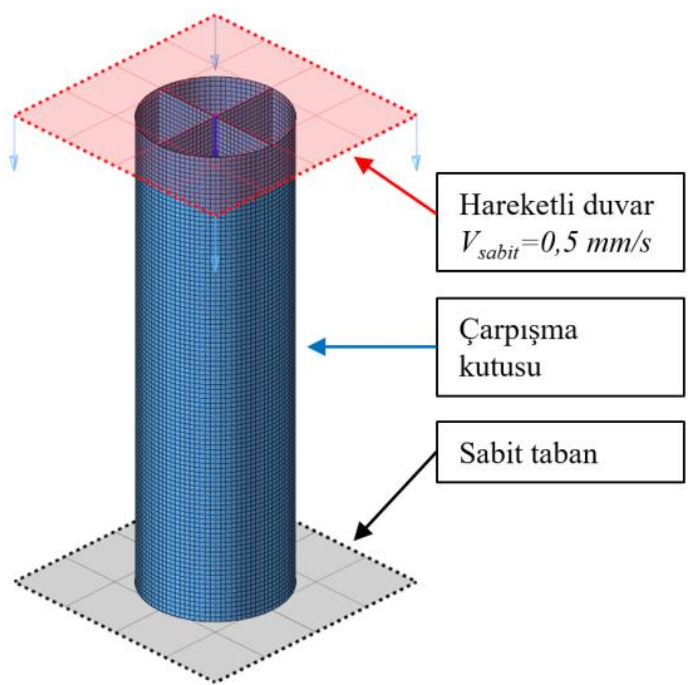

Şekil 2. Çarpışma kutusu simülasyon modeli

Çarpışma kutuları için kullanılan çift fazlı yüksek mukavemetli DP600 çeliği, AA6061-O alüminyum alaşımı ve AZ31B magnezyum alaşımlarının gerçek gerilme-gerinme eğrileri Şekil 3'te verilmiştir. AZ31B çeliğinin çekme ve basma durumlarındaki eğrileri farklı olduğu için her iki durumun gerinme-gerilme eğriside verilmiştir. Malzemelerin mekanik diğer mekanik özellikleri ise Çizelge 1'de verilmiştir.

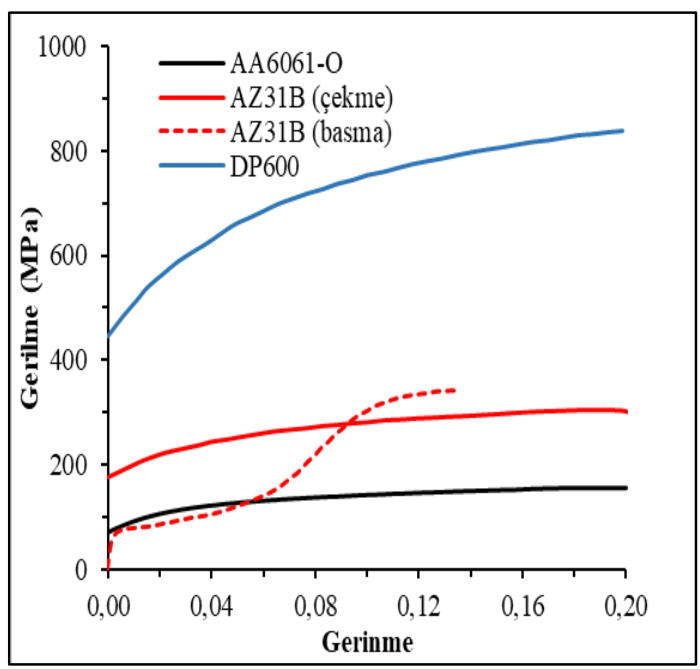

Şekil 3. AA6061-O [17], AZ31B [18] ve DP600 [19] malzemeleri gerçek gerilimgerinme eğrileri
Çizelge 1. Malzemelerin özellikleri

\begin{tabular}{|l|c|c|c|}
\hline & $\begin{array}{c}\text { Elastisite } \\
\text { Modülü } \\
(\mathrm{GPa})\end{array}$ & $\begin{array}{c}\text { Poisson } \\
\text { oran1 }\end{array}$ & $\begin{array}{c}\text { Yoğunluk } \\
\left(\mathrm{g} / \mathrm{cm}^{3}\right)\end{array}$ \\
\hline AA6061-O & 68 & 0,33 & 2,70 \\
\hline AZ31B & 44,8 & 0,35 & 1,77 \\
\hline DP600 & 210 & 0,3 & 8,00 \\
\hline
\end{tabular}

\subsection{Sonlu Elemanlar Modeli Doğrulama}

Sonlu elemanlar yöntemi ile çarpışma kutularının performanslarını incelemek için oluşturulan sonlu elemanlar modelinin doğrulanması karşılaştırmaların sağlı̆̆1 açısından çok önemlidir. $\mathrm{Bu}$ nedenle tasarımların karşılaştırılmasında önce sonlu elemanlar modellerinin doğrulanması yapılmıştır. Magnezyum, DP600 ve AA6061-O'dan farklı karakteristiğe sahip olduğu için iki farklı doğrulama yapılmıştır. İlk doğrulama için AA6061-O malzemeden yapılmış literatürde bulunan dairesel dört hücreli yapı üzerinden gerçekleştirilmiştir [17]. Doğrulama Zhang ve Zhang [17]'1n literatürde yaptığ 1 test ile aynı boyutlar ve $0,5 \mathrm{~mm} / \mathrm{s}$ 'lik sabit hızda basma şartlarında yapılan sonlu elemanlar basma analizi ile gerçekleştirilmiştir. Deneysel sonuç ile sonlu elemanlar analizi (SEA) sonucu oluşan katlanma modları Şekil 4'te verilmiştir. Sonuçlar incelendiğinde SEA ile elde edilen katlanma modlarının deneysel katlanma modları ile çok benzeştiği görülmektedir. Şekil 5'te deneysel test [17] ile sonlu elemanlar analizi ile elde edilen kuvvet yer değiştirme eğrileri verilmiştir. Her iki eğri kıyaslandığında dalgalanmaların ve değerlerin birbirine çok yakın olduğu görülmektedir.

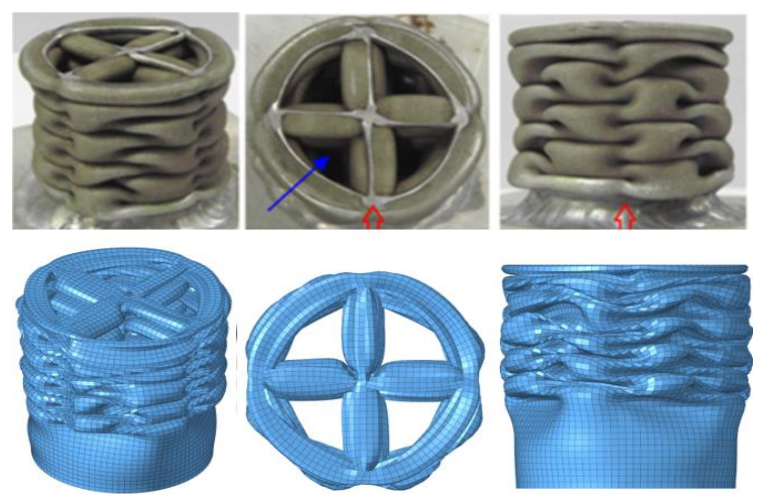

Şekil 4. Dairesel dört hücreli yapının deneysel [17] ve sonlu elemanlar modeli katlanma modları 


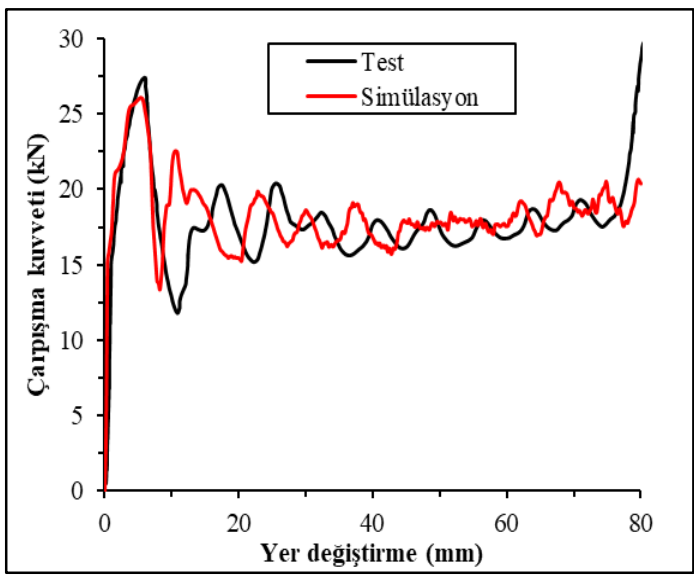

Şekil 5. Dairesel dört hücreli yapının deneysel [17] ve sonlu elemanlar modeli kuvvet yer değiştirme eğrileri

İkinci doğrulama çalışması ise Wang ve Gao [20] tarafından literatüre sunulan AZ31B malzemeden yapılmış dairesel bir yapı üzerinden gerçekleştirilmiştir. 1,00 mm et kalınlığına sahip $24 \mathrm{~mm}$ çapında ve $70 \mathrm{~mm}$ uzunluğundaki AZ31B malzemeden üretilmiş dairesel yapının literatür [20] ile aynı şartlarda olacak şekilde sonlu elemanlar analizi gerçekleştirilmiştir. Analizi sonucu elde edilen katlanma modları ve kuvvet yer değiştirme eğrileri sırasıyla Şekil 6 ve 7'de verilmiştir. Analiz sonucu elde edilen katlanma modlarının test verileri ile uyuştuğu görülmektedir. Analiz sonuçları ile test sonuçları ile benzer kopmalarında meydana geldiği görülmektedir. Benzer şekilde analiz sonucu elde edilen kuvvet yer değiştirme eğrisi ile test soncunda elde edilen eğri benzer karakteristiğe sahiptir.
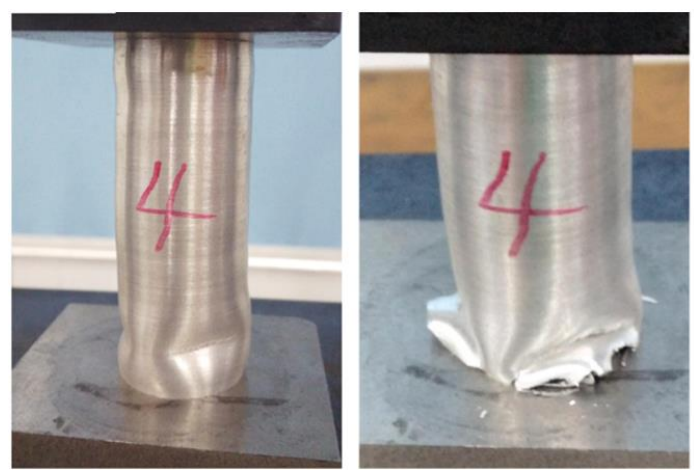
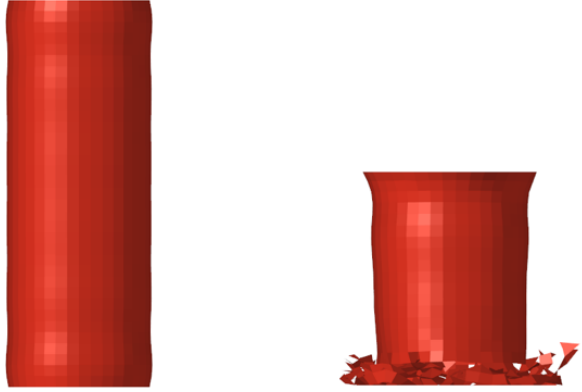

Şekil 6. AZ31B malzemeden yapılmı̣s dairesel yapının deneysel [20] ve sonlu elemanlar modeli katlanma modları

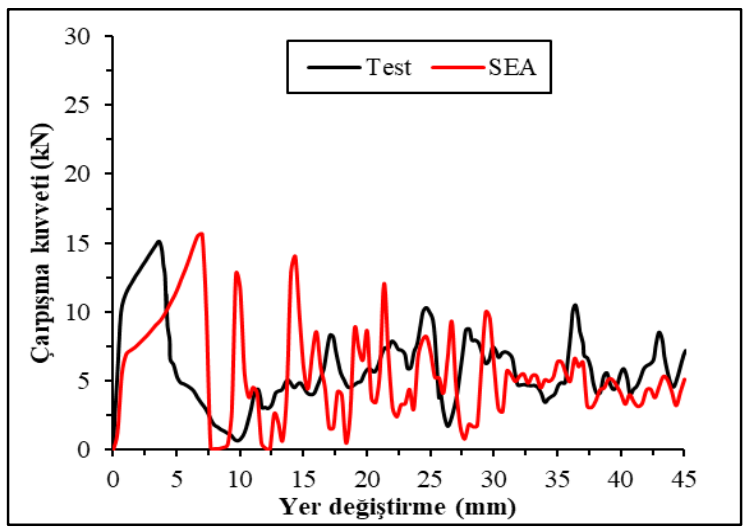

Şekil 7. AZ31B malzemeden yapılmış dairesel yapının deneysel [20] ve sonlu elemanlar modeli kuvvet yer değiştirme eğrileri

Her iki yapı içinde deneysel ve sonlu elemanlar analizleriyle elde edilmiş sayısal değerleri Çizelge 2'de verilmiştir. En büyük çarpışma kuvveti (EÇK) ve ortalama çarpışma kuvveti (OÇK) sonuçları incelendiğinde en büyük hatanın $\% \quad 8,82$ olduğu görülmektedir. Göreceli hatanın \% 10 içinde olduğu görülmektedir ki bu da mühendislik problemlerinde yeterli kabul edilmektedir [21].

Çizelge 2. Dairesel dört hücreli yap1 [17] ve AZ31B den dairesel yapının [20] test ve sonlu elemanlar modellerinin sayısal değerlerinin karşılaştırılması

\begin{tabular}{|l|l|c|c|c|}
\cline { 3 - 5 } \multicolumn{1}{c|}{} & Test & SEA & Hata $(\%)$ \\
\hline \multirow{2}{*}{$\begin{array}{l}\text { AA6061-O } \\
{[17]}\end{array}$} & EÇK $(\mathrm{kN})$ & 27,30 & 26,12 & 4,31 \\
\cline { 2 - 5 } & OÇK $(\mathrm{kN})$ & 17,64 & 18,33 & 3,90 \\
\hline \multirow{2}{*}{ AZ31B [20] } & EÇK (kN) & 15,29 & 15,66 & 2,42 \\
\cline { 2 - 5 } & OÇK $(\mathrm{kN})$ & 6,12 & 5,58 & 8,82 \\
\hline
\end{tabular}




\section{BULGULAR VE TARTIŞMA}

Kare, altıgen ve daire temel kesitlerinden elde edilen dokuz farklı çarpışma kutusunun AA6061O, AZ61B ve DP600 malzemelerle oluşturulan sonlu elemanlar modellerinin analiz sonuçları bu k1sımda incelenecektir. AA6061-O, AZ31B ve DP600 malzemeleri için çarpışma kutularının katlanma modları sırasıyla Şekil 8, Şekil 9 ve Şekil 10'da verilmiştir. Katlanmanın şekli ve sayısı çarpışma performansını önemli ölçüde etkilemektedir. AZ31B malzeme ile tasarlanmış çarpışma kutuları diğerlerinden ayrılmaktadır. Çünkü bu malzeme ile yapılan çarpışma kutuları yırtılmalara maruz kaldığı için katlanma meydana gelmemektedir. Bir miktar basma gerçekleştikten sonra bütün tüplerde yırtılmalar görülmektedir. Diğer malzemeler ile tasarlanan çarpışma kutularının katlanma modları incelendiğinde altıgen yapıların kare ve dairesel yapılara göre daha düzgün katlanmalar yaptığ 1 görülmektedir. Tek hücreli kare kesitli çarpışma kutuları daha uzun katlanma formlarına sahiptir. Enerji sönümleyici yapılarda uzun katlanma şekilleri çarpışma performansı düşürürken, kademeli düzgün katlanma modları enerji sönümleme performansını arttırır [22]. Çarpışma kutusunun hücre sayısının artmasıyla katlanmanın modlarını DP-K3 modeli hariç genel olarak kademeli hale getirmiştir.
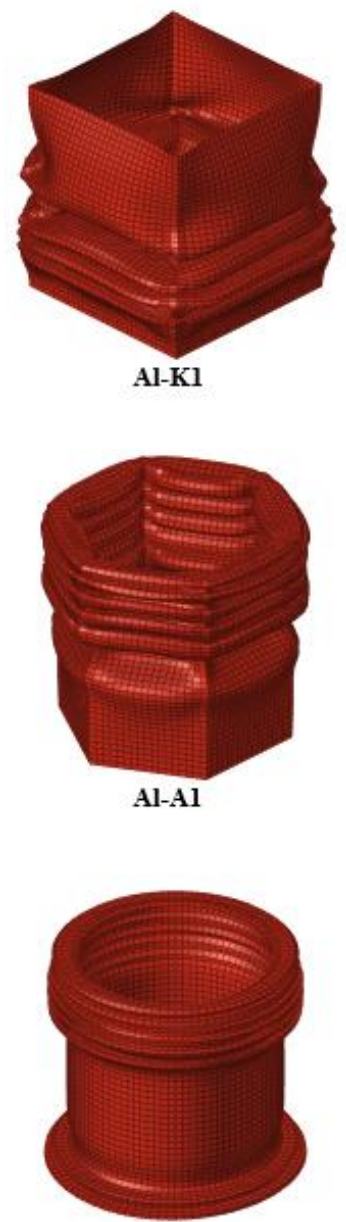

Al-D1
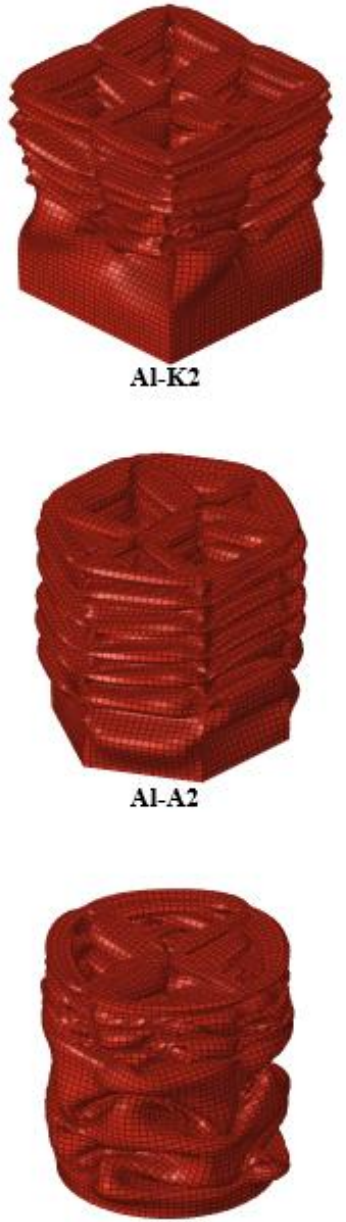

Al-D2
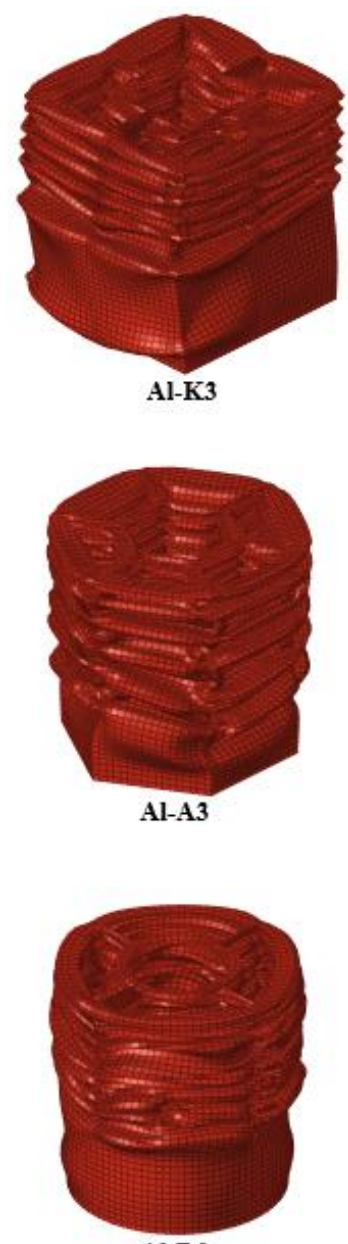

Al-D3

Şekil 8. AA6061-O malzeme ile tasarlanmış çarpışma kutularının katlanma modları 


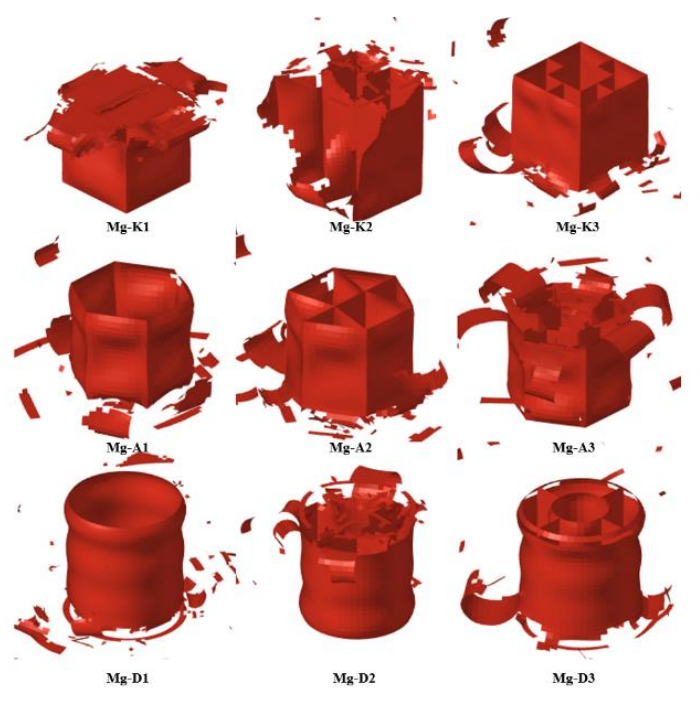

Şekil 9. AZ31B malzeme ile tasarlanmış çarpışma kutularının katlanma modları

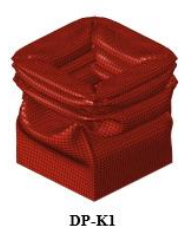

DP-K1
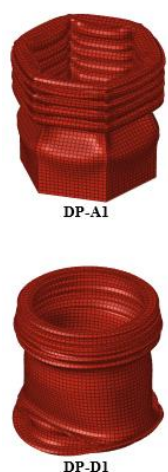
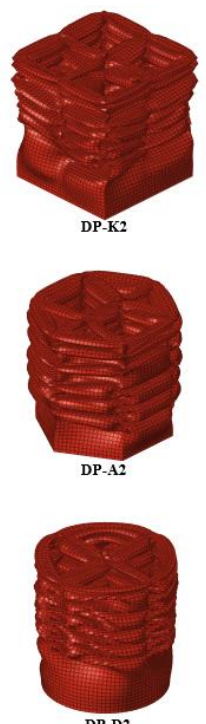

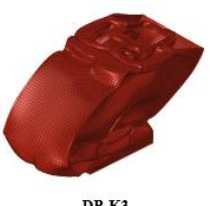

DP-K3
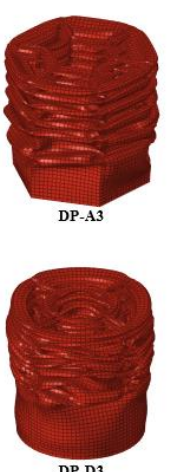

DP-D3
Şekil 10. DP600 malzeme ile tasarlanmıs çarpışma kutularının katlanma modları

AA6061-O, AZ31B ve DP600 malzemeleri ile modellenmiş çarpışma kutularının sonlu elemanlar analizi sonucu oluşan kuvvet yer değiştirme eğrileri sırasıyla Şekil 11, Şekil 12 ve Şekil 13'te verilmiştir. AZ31B ile tasarlanan çarpışma kutularının yırtılmaları dolayısıyla kuvvet yer değiştirme eğrileri diğer malzemeler ile tasarlanan tüplerden farklılık göstermiştir. Bu yapılarda ilk bir tepe noktasına ulaşılmış sonrasında ise ani düşüşler meydana gelmiştir. Devamında ise yırtılmalara bağlı olarak sık dalgalanmalar görülmektedir. Tek hücreli yapılarda tepe kuvveti daha düşükken çok hücreli yapılarda daha yüksek görülmektedir. Diğer malzeme ile tasarlanan tüplerde ise genel olarak hücre sayısının artması ile kuvvet grafiği daha yukarılara taşınmıştır. Böylece yapıların enerji sönümleme miktarları da artmaktadır. Ayrıca hücre sayısının artmasıyla dalga sayısı artmış ve dalga boyları kısalmıştır. Böylece bu yapıların enerji sönümleme kapasiteleri de artmıştır.

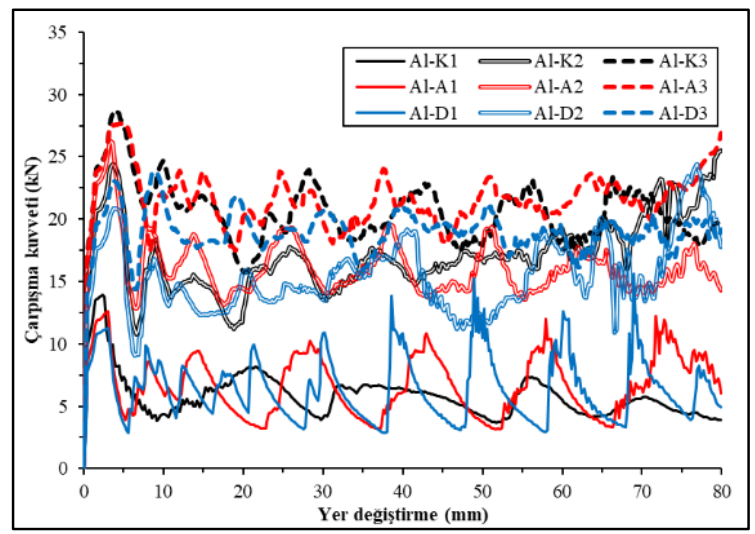

Şekil 11. AA6061-O malzeme ile tasarlanmış çarpışma kutularının kuvvet yer değiştirme eğrileri

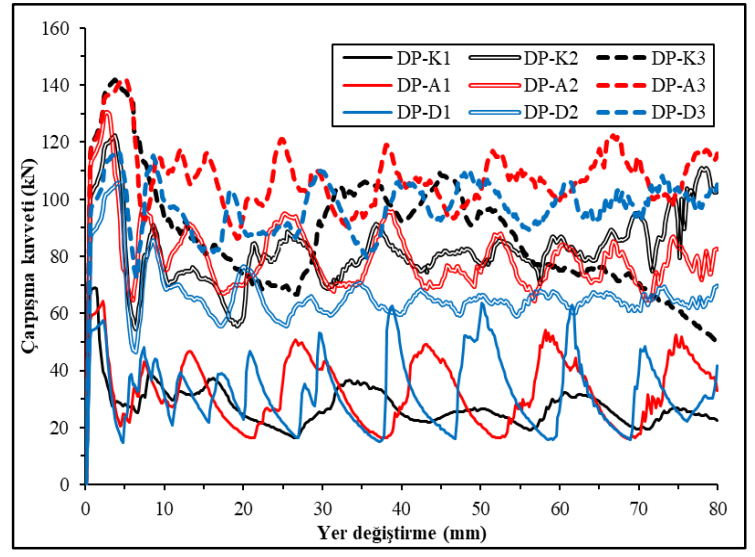

Şekil 12. AZ31B malzeme ile tasarlanmış çarpışma kutularının kuvvet yer değiştirme eğrileri 


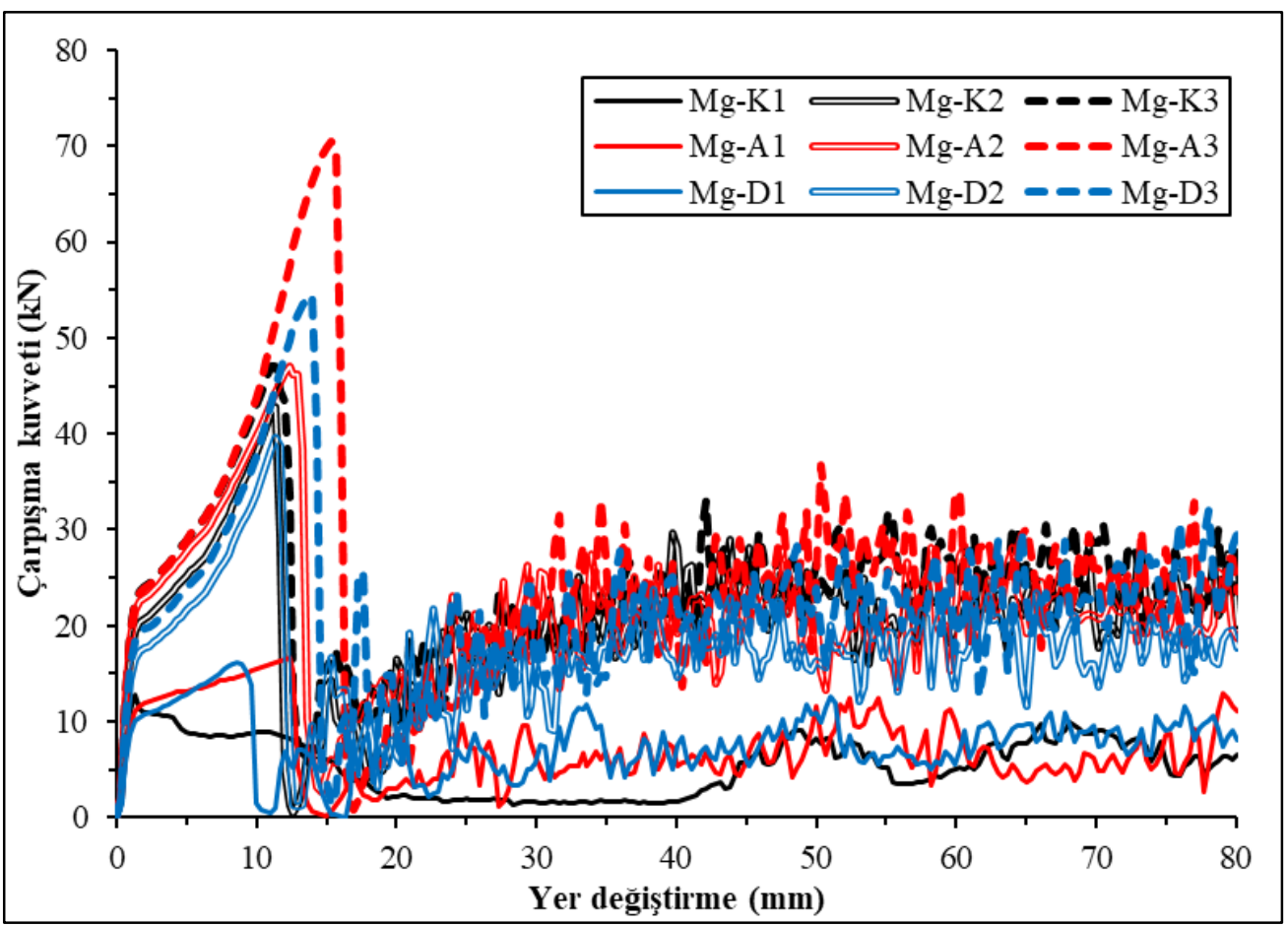

Şekil 13. DP600 malzeme ile tasarlanmış çarpışma kutularının kuvvet yer değiştirme eğrileri

Çarpışma kutularını kıyaslamak için belirlenen ve sonlu elemanlar analizleri sonucu elde edilen en büyük çarpışma kuvveti (EÇK), çarpışma kuvveti verimi (ÇKV) ve özgül enerji sönümleme kapasitesi (ÖES) değerleri sırasıyla Şekil 14, Şekil 15 ve Şekil 16'da verilmiştir. İyi bir enerji sönümleyici performansına sahip olması beklenen çarpışma kutularından düşük EÇK ve yüksek ÇKV ve ÖES değerleri beklenir. Çünkü EÇK değeri direkt olarak kaza esnasında oluşan hasar veya yaralanmanın büyüklüğüyle alakalıdır. Büyük EÇK değerlerinde hasar ve yaralanmalarda büyük olur bu nedenle daha küçük EÇK değerleri istenir. ÇKV ve ÖES değerleri ise enerji sönümleme kabiliyetini gösterdiği için mümkün olduğunda büyük olmaları beklenir.

Modellerin EÇK değerleri incelendiğinde en büyük değerlerin DP600 malzemelerde olduğu görülmektedir. Bu durum DP600 malzemesinin diğer malzemelere göre daha yüksek gerilmegerinme eğrisine sahip olmasıyla açıklanabilir. Ayrıca çok hücreli yapılarda az hücreli yapılara göre daha büyük EÇK değerleri görülmektedir.
Enerji sönümleyicinin kuvvet verimini veren ÇKV parametresi incelendiğinde ise çok hücreli yapıların daha yüksek değerlere sahip olduğu görülmektedir. AZ31B den tasarlanan yapilarda ise yırtılmalardan dolayı en küçük ÇKV değerleri görülmektedir. En yüksek ÇKV değerleri sırasıyla DP-D3, Al-D3 ve AlA3 de görülmektedir. Buradan çok hücreli dairesel yapının diğer yapılara göre daha iyi kuvvet verimine sahip olduğu söylenebilir. Birim kütle başına sönümlenen enerjiyi veren ÖES incelendiğinde ise yırtılmalara maruz kalmasına rağmen en yüksek değerlere magnezyum alaşımlarda ulaşıldığ görülmektedir. $\mathrm{Bu}$ durum magnezyum alaşımın kütlesine oranla daha yüksek enerji sönümlediğini göstermektedir. ÇKV değerinde olduğu gibi ÖES değerlerinde de çok hücreli yapılar az hücreli yapılara göre daha iyi sonuç vermiştir. En yüksek ÖES değerlerini sirasiyla $\mathrm{Mg}$-D3, DP-D3 ve Mg-A3 vermiştir. Buradan AZ31B ile tasarlanan çok hücreli yapıların yırtılmalara maruz kalmasına rağmen düşük yoğunluğu nedeniyle diğer alternatiflere göre birim kütle başına daha yüksek enerji sönümlediği görülmektedir. 


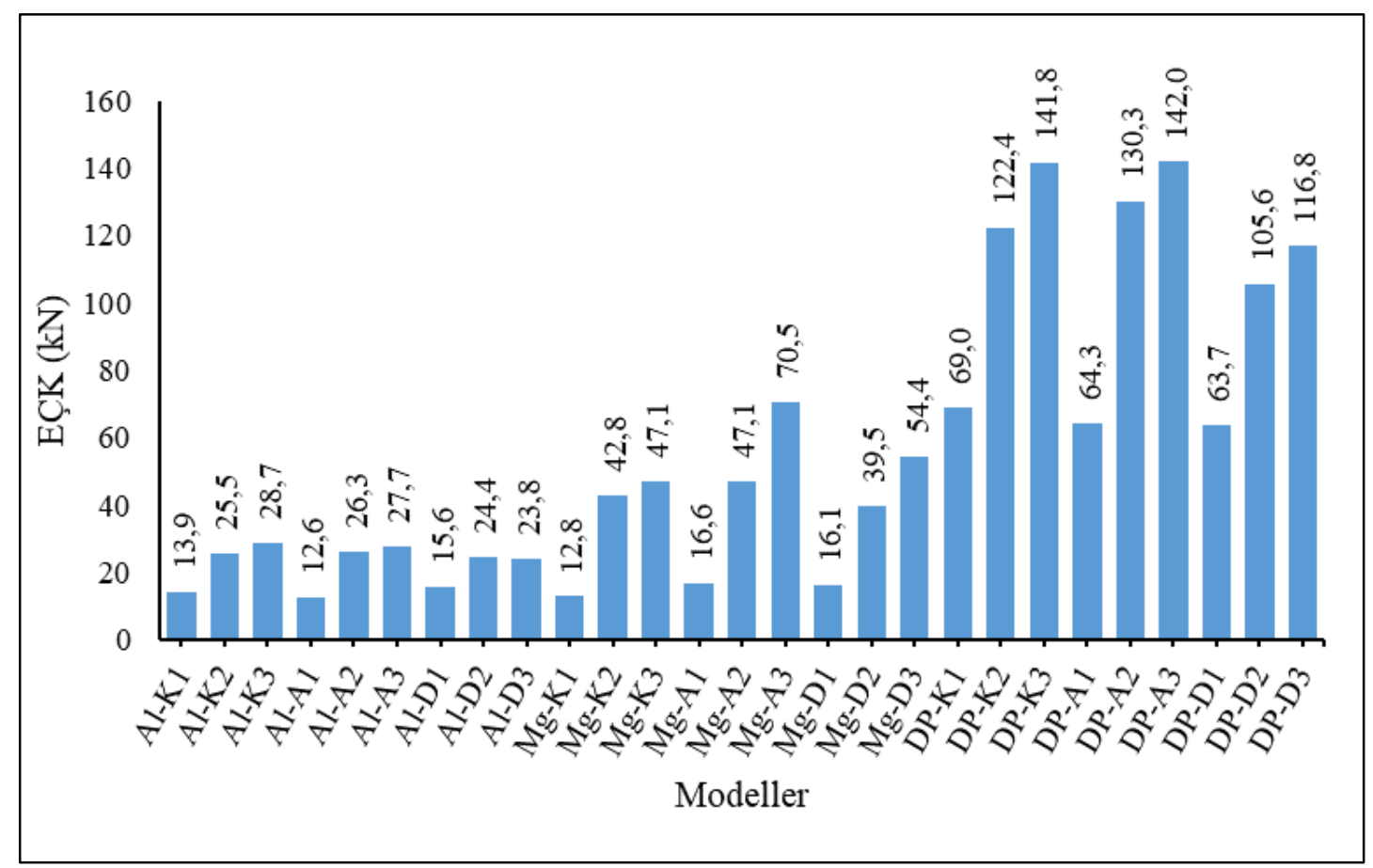

Şekil 14. Çarpışma kutularının EÇK değerleri

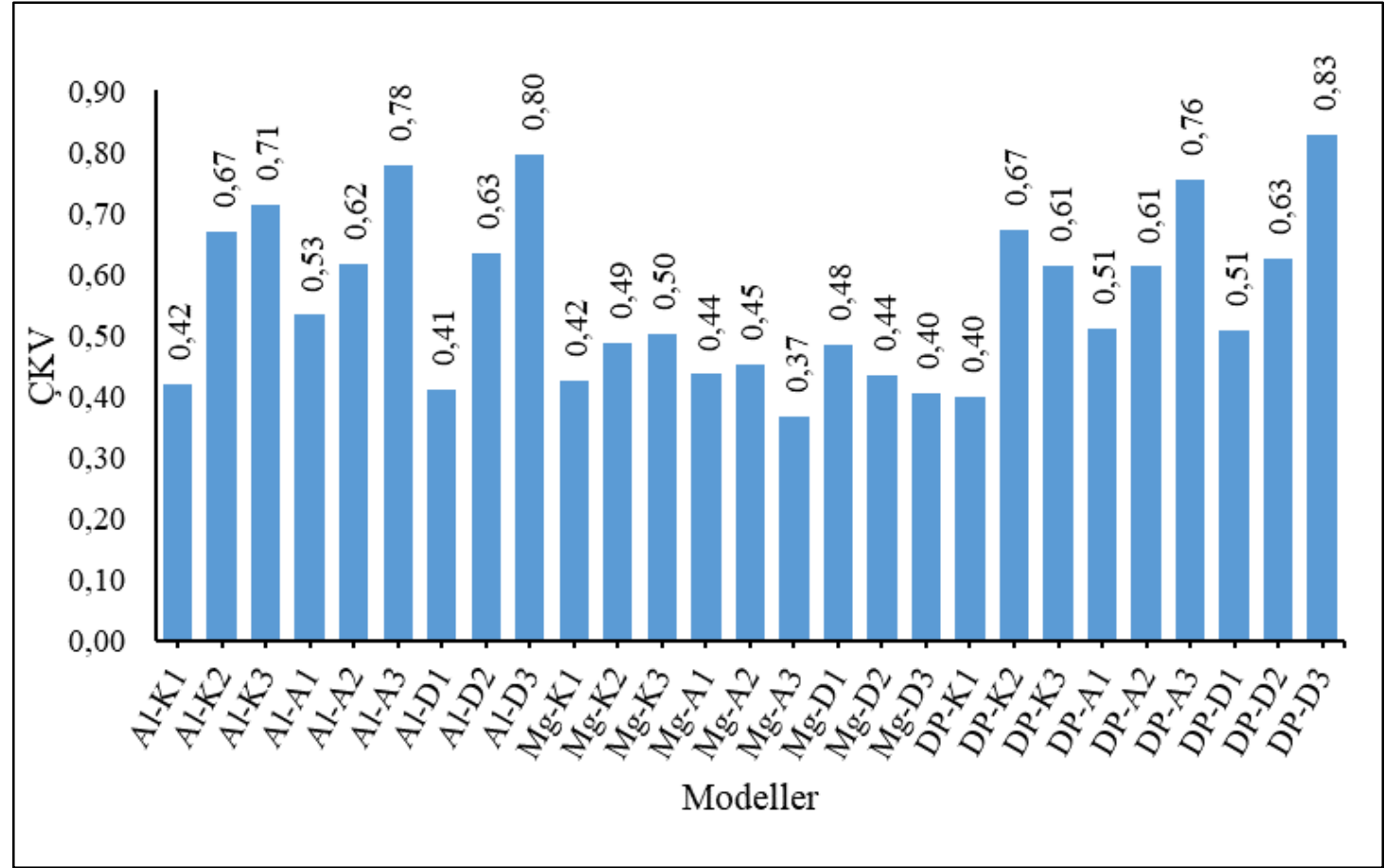

Şekil 15. Çarpışma kutularının ÇKV değerleri 


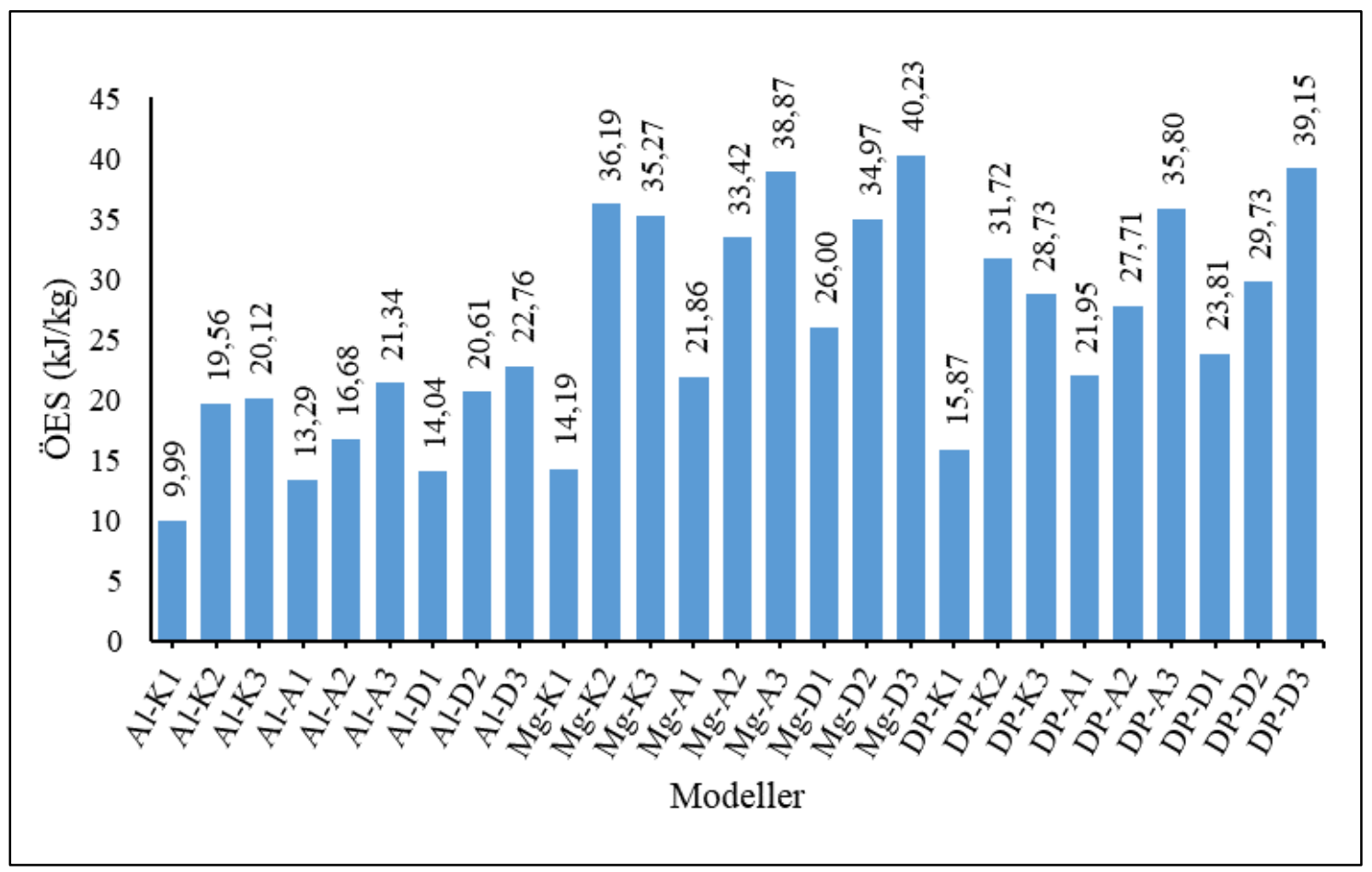

Şekil 16. Çarpışma kutularının ÖES değerleri

\section{SONUÇLAR}

$\mathrm{Bu}$ çalışmada çift fazlı yüksek mukavemetli DP600 çeliği, AA6061-O alüminyum alaşımı ve AZ31B magnezyum alaşımları kullanılarak farklı sayıda hücreye sahip dokuz farklı çarpışma kutusunun çarpışma performansları incelenmiştir. Çarpışma performansları $0,5 \mathrm{~mm} / \mathrm{s}$ 'lik sabit hızda basma şartlarında yapılan sonlu elemanlar ile incelenmiştir. Sonlu elemanlar modeli literatürde yer alan deneysel testler ile doğrulanmıştır. Çarpışma kutularının performansları literatürde en çok kullanılan çarpışma parametreleri olan çarpışma süresince edilen en büyük çarpışma kuvveti (EÇK), çarpışma kuvveti verimi (ÇKV) ve özgül enerji sönümleme kapasitesi (ÖES) üzerinden yapılmıştır. Çalışmada elde edilen çıktılar şöyledir:

1. Çok hücreli yapıların EÇK, ÇKV ve ÖES değerleri tek hücreli yapılara göre daha yüksek olmaktadir.
2. Çok hücreli yapıların kuvvet yer değiştirme eğrileri daha kısa ve daha fazla dalgaya sahiptir.

3. AZ31B ile tasarlanan çarpışma kutularında basmanın hemen başlarında yırtılma görülmesinden dolayı ÇKV değerleri diğer tüplere göre daha düşüktür.

4. AZ31B ile tasarlanan çarpışma kutularında yırtılma görülmesine rağmen düşük yoğunlukları nedeniyle yüksek ÖES değerleri görülmektedir.

5. En yüksek ÖES değerlerini sırasıyla Mg-D3, DPD3 ve Mg-A3 çarpışma kutuları vermiştir.

\section{KAYNAKLAR}

1. Abramowicz, W., Jones, N., 1984. Dynamic Axial Crushing of Square Tubes, International Journal of Impact Engineering, 2(2), 179-208.

2. Langseth, M., Hopperstad, O.S., Berstad, T., 1999. Crashworthiness of Aluminium Extrusions: Validation of Numerical Simulation, Effect of Mass Ratio and Impact Velocity, International Journal of Impact Engineering, 22(9-10), 829-854. 
3. Rossi, A., Fawaz, Z., Behdinan, K., 2005. Numerical Simulation of the Axial Collapse of Thin-walled Polygonal Section Tubes. Thinwalled Structures, 43(10), 1646-1661.

4. Hou, S., Li, Q., Long, S., Yang, X., Li, W., 2007. Design Optimization of Regular Hexagonal Thin-walled Columns with Crashworthiness Criteria, Finite Elements in Analysis and Design, 43(6-7), 555-565.

5. Guillow, S.R., Lu, G., Grzebieta, R.H., 2001. Quasi-static Axial Compression of Thinwalled Circular Aluminium Tubes, International Journal of Mechanical Sciences, 43(9), 2103-2123.

6. Zarei, H.R., Kröger, M., 2006. Multiobjective Crashworthiness Optimization of Circular Aluminum Tubes, Thin-walled Structures, 44(3), 301-308.

7. Tarlochan, F., Samer, F., Hamouda, A.M.S., Ramesh, S., Khalid, K., 2013. Design of Thin Wall Structures for Energy Absorption Applications: Enhancement of Crashworthiness Due to Axial and Oblique Impact Forces, Thin-walled Structures, 71, 7-17.

8. Yamashita, M., Gotoh, M., Sawairi, Y., 2003. Axial Crush of Hollow Cylindrical Structures with Various Polygonal Cross-sections: Numerical Simulation and Experiment, Journal of Materials Processing Technology, 140(1-3), 59-64.

9. Zhang, X., Zhang, H., 2013. Energy Absorption of Multi-cell Stub Columns Under Axial Compression, Thin-Walled Structures, 68, 156-163.

10. Huang, H., Xu, S., 2019. Crashworthiness Analysis and Bionic Design of Multi-cell Tubes Under Axial and Oblique Impact Loads, Thin-walled Structures, 144, 106333.

11. Qiu, N., Gao, Y., Fang, J., Feng, Z., Sun, G., Li, Q., 2015. Crashworthiness Analysis and Design of Multi-cell Hexagonal Columns Under Multiple Loading Cases, Finite Elements in Analysis and Design, 104, 89-101.

12. Çavuşoğlu, O., Gürün, H., 2014. Deformasyon Hizının DP600 ve DP780 Sac Malzemelerin Mekanik Özelliklerine ve Derin Çekme İşlemine Etkilerinin İncelenmesi, Gazi
Üniversitesi Mühendislik Mimarlı Fakültesi Dergisi, 29(4), 777-784.

13. Demirci, E., Yildiz, A.R., 2018. An Investigation on the Crash Performance of Magnesium, Aluminum and Advanced High Strength Steels and Different Cross-sections for Vehicle Thinwalled Energy Absorbers, Materials Testing, 60(7-8), 661-668.

14. Kurtuluş, E., Tekin, G., 2021. Conversion of Aluminum Front Bumper System to Magnesium Material by Using Design of Experiment Method, International Journal of Automotive Science and Technology, 5(1), 34-42.

15. Albak, E.İ., 2020. Effects of Sections Added to Multi-cell Square Tubes on Crash Performance, Materials Testing, 62(5), 471-480.

16. Altair Hyperworks, 2019. Radioss user guide.

17. Zhang, X., Zhang, H., 2014, Axial Crushing of Circular Multi-cell Columns, International Journal of Impact Engineering, 65, 110-125.

18. Steglich, D., Bohlen, J., Tian, X., Riekehr, S., Kashaev, N., Bargmann, S., Letzig, D., Kainer, K.U., Huber, N., 2013. Crashworthiness of Magnesium Sheet Structures, In Materials Science Forum, 765, 590-594.

19. Xu, F., Sun, G., Li, G., Li, Q., 2014. Experimental Study on Crashworthiness of Tailor-welded Blank (TWB) Thin-walled High-strength Steel (HSS) Tubular Structures, Thin-walled Structures, 74, 12-27.

20. Wang, S., Gao, G., 2018. Performance of Extruded Magnesium Alloy AZ31B Circular Tubes Under Uniaxial Compression, Thin-walled Structures, 131, 464-474.

21. Shu, C., Zhao, S., Hou, S., 2018. Crashworthiness Analysis of Two-layered Corrugated Sandwich Panels Under Crushing Loading, Thin-walled Structures, 133, 42-51.

22. Sun, G., Pang, T., Fang, J., Li, G., Li, Q., 2017. Parameterization of Criss-cross Configurations for Multiobjective Crashworthiness Optimization, International Journal of Mechanical Sciences, 124, 145-157. 